\title{
Regulation of dopamine receptors in the MtT/W15 transplantable pituitary tumor by estrogen
}

\author{
Ricardo V. Lloyd and Kristina L. Fields \\ Department of Pathology, University of Michigan Medical School, Ann Arbor, MI 48109 (U.S.A.)
}

(Received 12 August 1985; accepted 24 October 1985)

Key words: prolactin; growth hormone; spiperone; diethylstilbestrol; estrogen

\section{Summary}

We investigated the effects of estrogens on the regulation of dopamine receptors in the MtT/W15 transplantable rat pituitary tumor. Diethylstilbestrol (DES) and $17 \beta$-estradiol treatment in female rats significantly decreased the number of dopamine binding sites $\left(B_{\max }\right)$ from $85 \pm 3.9 \mathrm{fmol} / \mathrm{mg}$ protein in untreated rats to $9.2 \pm 1.2$ and $8.2 \pm 2.8 \mathrm{fmol} / \mathrm{mg}$ protein in DES and $17 \beta$-estradiol-treated rats, respectively, while the binding affinities $\left(K_{\mathrm{d}}\right)$ did not change significantly. Testosterone treatment did not change the $B_{\max }$, while ovariectomy resulted in a significant increase in the $B_{\max }(146.3 \pm 6.7 \mathrm{fmol} / \mathrm{mg}$ protein $)$. The effects of DES on the $B_{\max }$ were reversible, since removal of the DES for one week before sacrificing the animals led to a marked increase in the $B_{\max }(54.9 \pm 3.1 \mathrm{fmol} / \mathrm{mg}$ protein).

Pituitaries from normal female rats treated with DES for 6 and 9 weeks had a significant decrease in the $B_{\max }$.

These results show that the number of dopamine binding sites in the membranes of MtT/W15 tumors is decreased by estrogen treatment and that this effect is reversible after removal of the estrogenic stimulus.

The MtT/W15 transplantable pituitary tumor which secretes PRL and GH was initiated by Furth et al. (1956) by diethylstilbestrol (DES) treatment in rats. Although this tumor was initially dependent on estrogens for growth, it subsequently became autonomous. Recently Cronin et al. (1982) reported that the MtT/W15 tumor had dopamine receptors, but that this tumor was refractory to dopaminergic inhibition of prolactin release. Earlier reports indicated that bromocriptine did not inhibit prolactin release from the MtT/W15 tumor (Lamberts and MacLeod, 1979).

Address correspondence to: R.V. Lloyd, M.D., Department of Pathology, University of Michigan Medical School, 1315 Catherine Rd., Ann Arbor, MI 48109 (U.S.A.).
We have recently observed that the growth of the MtT/W15 tumor was inhibited by DES (Lloyd et al., 1985). This observation was surprising in light of the origin of this tumor. However, other recent reports have indicated that growth of the MtTF4 transplantable pituitary tumor was also inhibited by estrogen (Morel et al., 1982). The MtTF4 pituitary tumor has recently been reported to have dopamine receptors which are down-regulated by $17 \beta$-estradiol treatment (André et al., 1982; Albaladejo et al., 1984). We previously noted that the DES inhibition of $\mathrm{MtT} / \mathrm{W} 15$ tumor growth was associated with a relative increase in the $\mathrm{GH}$-producing cells and a decrease in the PRL-producing cells (Lloyd et al., 1985). Because of these findings we investigated the MtT/W15 
tumor for the presence of dopamine receptors and examined the regulation of these receptors by DES and several steroid hormones. The effects of DES on dopamine receptors in the $\mathrm{MtT} / \mathrm{W} 15$ tumor were compared with the effects of DES on dopamine receptors in normal and in hyperplastic rat pituitary tissues after DES treatment.

\section{Materials and methods}

\section{Animals}

Forty-day-old Wistar-Furth female rats (Harlan, Madison, WI) were inoculated with $2 \mathrm{~mm}^{3}$ pieces of minced MtT/W15 tumor subcutaneously (s.c.) over the right lower flank. This tumor was obtained from Dr. Bogden at the Mason Research Institute (Worcester, MA) and has been maintained in our laboratory for 3 years with more than 20 passages. The tumors secrete large amounts of PRL and GH and contain immunoreactive PRL and $\mathrm{GH}$ in the cytoplasm (Lloyd et al., 1985). Animals were exposed to a cycle of $12 \mathrm{~h}$ light and $12 \mathrm{~h}$ darkness. Food and water were available ad libitum. Silastic tubes with $10 \mathrm{mg}$ of DES, $17 \beta$ estradiol or testosterone were prepared as previously described (Lloyd et al., 1985). Four weeks after tumor implantation 5 animals per group with palpable tumors were given $10 \mathrm{mg}$ of DES, estrogen, or testosterone in Silastic tubes. Control animals received empty Silastic tubes. After various periods of treatment, animals were sacrificed by decapitation between 9 and 11 a.m. In some experiments after 1 week of DES treatment the Silastic tubes were removed under light anesthesia and these 5 animals were followed for one week before sacrificing. Another group of 8 rats was ovariectomized one week after tumor implantation. These animals were subsequently sacrificed 6 weeks after ovariectomy. Tumor tissues were used for dopamine receptor studies and for immunohistochemical studies.

In other experiments groups of five 40-day-old Wistar-Furth female rats without tumors received $10 \mathrm{mg}$ of DES in Silastic tubes. After 3,6 and 9 weeks, the rats were sacrificed between 9 and 11 a.m. and the pituitaries were used for dopamine receptors and immunohistochemical studies.

\section{Dopamine receptor binding studies}

The MtT/W15 tumors and pituitary tissues were rapidly excised after decapitation. Tumor cells and pituitary tissues were separated from adjacent areas of necrosis and hemorrhage. Sections of the tumors were fixed in neutral buffered formalin and stained with hematoxylin and eosin to confirm that non-necrotic pituitary tissue was present. The tissues were placed into ice-cold buffer (15 mM Tris, $120 \mathrm{mM} \mathrm{NaCl}, 5 \mathrm{mM} \mathrm{KCl}, 1 \mathrm{mM}$ $\mathrm{MgCl}_{2}, 2 \mathrm{mM} \mathrm{CaCl}, 0.1 \mathrm{mM}$ EDTA, $0.1 \%$ ascorbate and $12.5 \mu \mathrm{M}$ nialamide, $\mathrm{pH} 7.3$ ) which was used throughout the receptor study. The tissues were minced with sterile scalpel blades, transferred to fresh buffer ( 6 vols./wet weight) and homogenized with a Thomas Homogenizer 4 times for $60 \mathrm{~s}$ each time. The homogenate was filtered through 4 layers of cheesecloth then centrifuged at $1000 \times \mathrm{g}$ for $10 \mathrm{~min}$ at $4^{\circ} \mathrm{C}$. The supernatant was centrifuged at $70000 \times g$ for $60 \mathrm{~min}$ and the pellet was resuspended in ice-cold buffer and homogenized for $20 \mathrm{~s}$. This homogenate was divided into samples and stored frozen at $-80^{\circ} \mathrm{C}$ for 2 months or less with no apparent change in the dopamine receptor content. Aliquots were taken for protein determinations (8). The dopamine receptor assay was performed at $37^{\circ} \mathrm{C}$ using the procedure of Cronin et al. $(1979,1982)$ with $\left[{ }^{3} \mathrm{H}\right]$ spiperone ([1-phenyl-4- $\left.{ }^{3} \mathrm{H}\right]$ spiroperidol, spec. act. 22-26 $\mathrm{Ci} / \mathrm{mmol}$, New England Nuclear, MA). The $\left[{ }^{3} \mathrm{H}\right]$ spiperone was diluted in $5 \%$ ethanol buffer. Bromocriptine (Sandoz, New Jersey), haloperidol, spiperone (Janssen Pharmaceutical, Beerse, Belgium) and Pergolide (Eli Lilly, Indianapolis, IN) were generous gifts. $d$ - and $l$-Butaclamol were from Research Biochemicals (Wayland, MA) while dopamine, epinephrine and norepinephrine were from Sigma (St. Louis, MO). Duplicate samples were used. Protein concentrations ranged from 0.6 to $0.9 \mathrm{mg} / \mathrm{ml}$, and the total volume of the assay tube was $0.6 \mathrm{ml}$. After incubation at $37^{\circ} \mathrm{C}$, the samples had $3 \mathrm{ml}$ of cold Tris buffer added. They were kept on ice 5-10 min before filtration and then washed 3 times with $3 \mathrm{ml}$ of ice-cold buffer each time for 20-30 s. The radioactivity was trapped on Whatman GF/C filters and after drying for $2 \mathrm{~h}$ at $60^{\circ} \mathrm{C}$ was measured by liquid scintillation counting in Scintiverse (Fisher, Detroit, MI) with a machine counting efficiency of $30-40 \%$. Specific binding was defined as the difference between the radioactivity bound to the 
membranes in the absence (total binding) and in the presence of a 1000 -fold excess $(2 \mu \mathrm{M}) d$ butaclamol (non-specific binding). The maximal number of binding sites $\left(B_{\max }\right)$ and the apparent dissociation constant $\left(K_{\mathrm{d}}\right)$ were determined from Scatchard plots (Scatchard, 1949) which were fitted to the experimental data by least-squares regression analysis. Statistical analysis was done with the Student $t$-test.

\section{Results}

Dopamine receptor binding capacity was detectable in the MtT/W15 tumors from all untreated animals. Specific binding of $\left[{ }^{3} \mathrm{H}\right]$ spiperone increased linearly between 0.3 and $1.2 \mathrm{mg}$ /assay tube. Specific binding to the membrane preparation was reduced by more than $95 \%$ after preincubation with $0.25 \%$ trypsin or protease $\mathrm{K}$, for 30

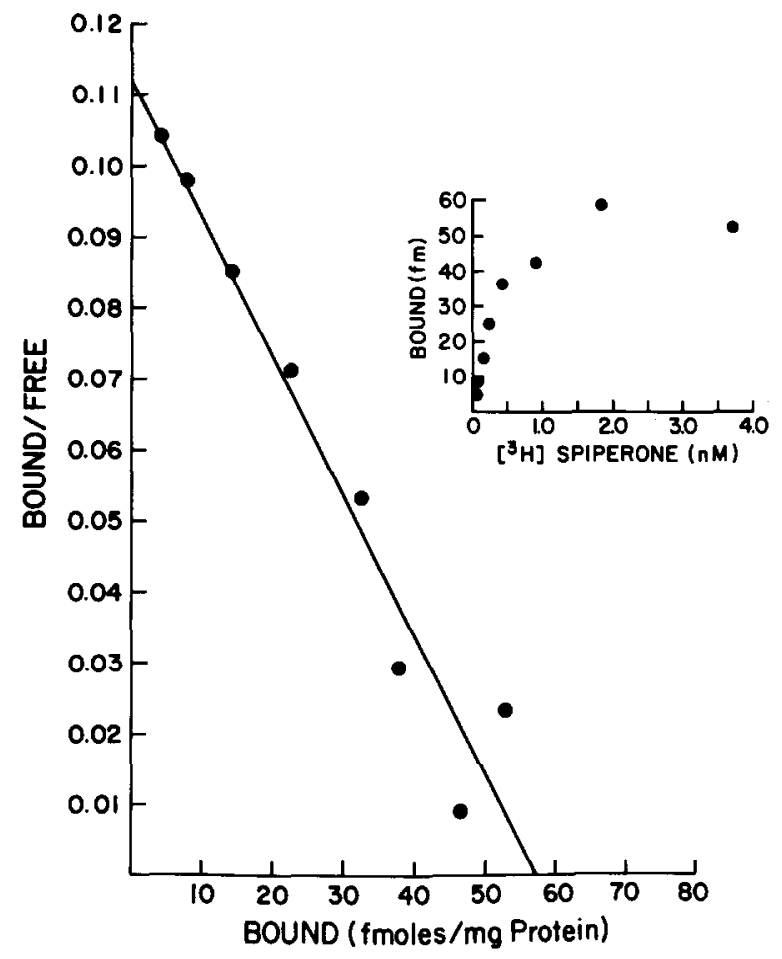

Fig. 1. A Scatchard and direct (inset) plot of a saturation isotherm experiment. The $K_{\mathrm{d}}$ in this experiment was $0.516 \mathrm{nM}$ and maximal binding was $57 \mathrm{fmol} / \mathrm{mg}$ assay protein. Concentrations of $\left[{ }^{3} \mathrm{H}\right]$ spiperone from 0.117 to $3.76 \mathrm{nM}$ were studied. The regression line significantly approximated the experimental points $\left(r^{2}=0.98\right)$. min at $37^{\circ} \mathrm{C}$, but not with $0.25 \%$ ribonuclease. Specific binding as a function of incubation temperature for $30 \mathrm{~min}$ was shown to decrease in this order: $37^{\circ} \mathrm{C}, 23^{\circ} \mathrm{C}, 4^{\circ} \mathrm{C}$ and $60^{\circ} \mathrm{C}$. The optimal $\mathrm{pH}$ for specific binding was 7.2, while $\mathrm{pH} 2$ reduced specific binding to $20 \%$ of that seen at $\mathrm{pH}$ 7.2. All binding assays were done at $37^{\circ} \mathrm{C}$ for 30 min at $\mathrm{pH} 7.2$. The protein concentration used in each assay was $0.6-0.9 \mathrm{mg} /$ assay tube. With these conditions the specific binding represented from 40 to $82 \%$ of total binding. Specific binding did not change within the maximum 2 -month period of storage of the homogenate at $-80^{\circ} \mathrm{C}$. A typical Scatchard plot is shown in Fig. 1. The equilibrium dissociation constant, $K_{\mathrm{d}}$, for 5 experiments was $0.614 \pm 0.107 \mathrm{nM}$ and the total number of binding sites was $87 \pm 3.9 \mathrm{fmol} / \mathrm{mg}$ assay protein for plasma membranes from the MtT/W15 tumor.

The character of the binding was determined by competition experiments (Table 1). The MtT/W15 tumor binding sites were stereoselective with preferential binding of the $d$-butaclamol isomer. The rank order of potency of various ligands at these sites was similar to the protency profile of dopamine receptors previously characterized in the anterior pituitary gland and in $\mathrm{MtT} / \mathrm{W} 15$ tumors (Table 1).

The results of various treatments on the $B_{\text {max }}$ of the MtT/W15 tumor are summarized in Fig. 2. Ovariectomy caused an increase in the $B_{\max }$, while treatment with DES and $17 \beta$-estradiol for one week produced a significant decrease. After one week of DES treatment the MtT/W15 tumors weighed $1.2 \pm 0.6 \mathrm{~g}$, while tumors from control animals weighed $2.5 \pm 1.3 \mathrm{~g}$. Three weeks of DES treatment resulted in $\mathrm{MtT} / \mathrm{W} 15$ tumors weighing $0.74 \pm 0.2 \mathrm{~g}$, while tumors from control animals weighed $27.8 \pm 9 \mathrm{~g}$ (mean \pm SEM for 4 determinations). The pituitaries of control rats and rats treated with DES for 1 and 3 weeks weighed $7.6 \pm 0.6 \mathrm{mg}, 10.7 \pm 0.4 \mathrm{mg}$, and $23.6 \pm 1.0 \mathrm{mg}$ respectively (mean \pm SEM for 4 determinations). Treatment with testosterone did not change the $B_{\text {max }}$. Preliminary experiments showed that after 2 and 3 weeks of DES treatment dopamine receptor binding was not measurable in the tumors. The dopamine receptor affinities after various treatments were unchanged. The $K_{\mathrm{d}} \mathrm{s}$ for tumors from untreated controls, ovariectomized groups, testos- 
TABLE 1

COMPETITION BY VARIOUS AGENTS FOR $\left[{ }^{3} \mathrm{H}\right]$ SPIPERONE BINDING TO THE MTT/W15 TRANSPLANTABLE PITUITARY TUMOR

The apparent $K_{\mathrm{i}}$ was determined in independent experiments with at least 3 competitor concentrations. The apparent $K_{\mathrm{i}} \pm$ standard error of the mean was calculated according to the equation $K_{\mathrm{i}}=\mathrm{IC}_{50}\left(1+\mathrm{C} / K_{\mathrm{d}}\right)$ where the $\mathrm{IC}_{50}$ is the concentration of the drug which competes for $50 \%$ of the specific binding defined by $2 \mu \mathrm{M} \mathrm{d}$-butaclamol. C is the concentration of [ $\left.{ }^{3} \mathrm{H}\right]$ spiperone $(0.117-0.94$ $\mathrm{nM}) . K_{\mathrm{d}}$ was determined from saturation isotherm studies $(0.61 \mathrm{nM})$. Specific binding was $50-70 \%$ of total binding.

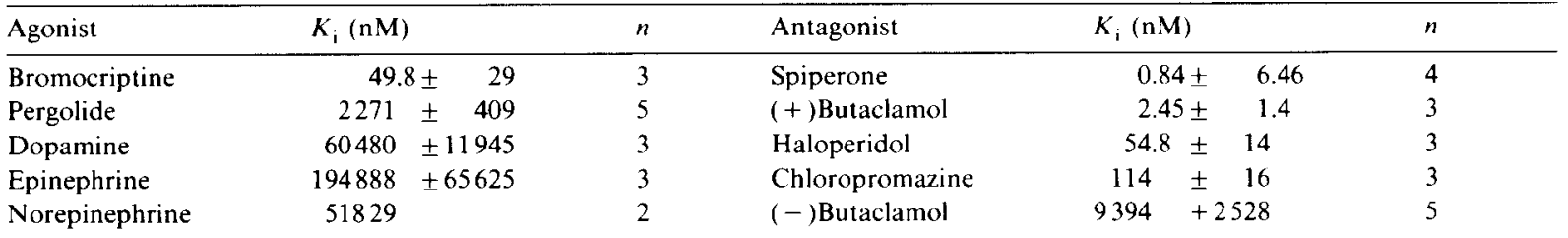

terone-, DES- and estradiol-treated groups were $0.61 \pm 0.13, \quad 0.58 \pm 0.12, \quad 0.67 \pm 0.12, \quad 0.69 \pm 0.13$ and $0.94 \pm 0.49$ respectively.

To evaluate the reversibility of the down-regulation of dopamine receptors by DES, a group of 5 rats was treated with DES for one week. The DES was removed for one week before the animals were sacrificed and dopamine receptor levels measured. The $B_{\max }$ was $54.9 \pm 3 \mathrm{fmol} / \mathrm{mg}$ protein, while the $K_{\mathrm{d}}$ was $0.90 \pm 0.26$, incidating that the dopamine receptor levels increased after removal of DES without any significant changes in the affinity for the receptor.

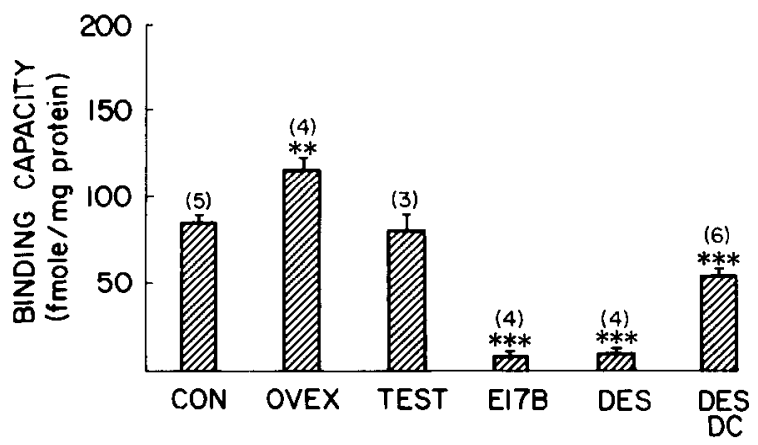

Fig. 2. The effects of various treatments on the MtT/W15 dopaminergic binding capacity. Each value for binding capacity is the mean \pm SEM. Concentrations of $\left[{ }^{3} \mathrm{H}\right]$ spiperone from 0.117 to $1.88 \mathrm{nM}$ were used. The number of binding experiments is shown in parentheses. Significant differences included ${ }^{*} P<$ $0.05,{ }^{* *} P<0.01$ and ${ }^{* * *} P<0.001$. CON, control; OVEX, ovariectomy; TEST, testosterone; E17B, $17 \beta$-estradiol; DES, diethylstilbestrol; DES DC, diethylstilbestrol discontinued for 1 week before sacrificing rats.
When the effects of estrogen on the non-tumorous pituitary were cvaluated after DES treatment for zero, 3, 6 and 9 weeks, there was a significant decrease in dopamine receptor levels after 6 and 9 weeks of DES treatment (Fig. 3). Although the $B_{\text {max }}$ was greater than that seen with the $\mathrm{MtT} / \mathrm{W} 15$ tumors, the $K_{\mathrm{d}}$ was in the same range with values of $0.84 \pm 0.19,0.95 \pm 0.25,0.52 \pm 0.28$ and $0.83 \pm$ 0.23 in normal pituitaries and pituitary tissues after 3,6 and 9 weeks of DES treatment respectively.

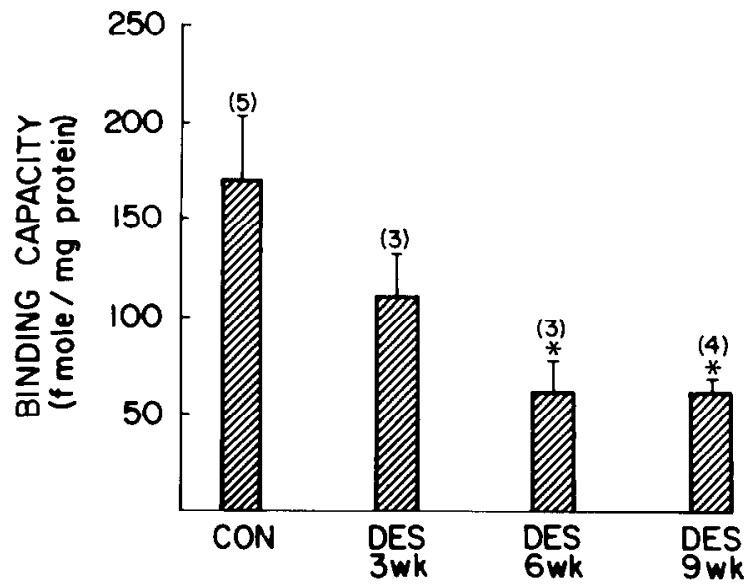

Fig. 3. The effects of various periods of DES treatment on the anterior pituitary gland dopaminergic binding capacity. Concentrations of $\left[{ }^{3} \mathrm{H}\right]$ spiperone from 0.117 to $1.88 \mathrm{nM}$ were used. Each value for binding capacity is the mean \pm SEM. The number of binding experiments is shown in parentheses. Significant differences included ${ }^{*} P<0.05{ }^{* *} P<0.01$ and ${ }^{* * *} P<0.001$. 


\section{Discussion}

This study examines the effects of estrogen treatment on dopamine binding of $\left[{ }^{3} \mathrm{H}\right]$ spiperone to dopamine receptors of $\mathrm{MtT} / \mathrm{W} 15$ tumor cell membranes. DES and estrogen treatment resulted in a decrease of the maximal number of binding sites while the affinity for the receptor was not modified. This effect was not seen with testosterone, which suggests that there is hormone specificity. The effects of estrogens on the dopamine receptor of $\mathrm{MtT} / \mathrm{W} 15$ tumors is analogous to the effects of estradiol on the MtTF4 tumor dopamine receptor levels (Albaladejo et al., 1984). However, the present study adds several new observations about the regulation of dopamine receptor levels in the MtT/W15 tumor. The first is that ovariectomy increases the $B_{\max }$ of the tumor membrane. We have previously shown that the MtT/W15 tumor grows at a slower rate after ovariectomy, indicating that a certain level of estrogen is still needed for optimal growth of this tumor (Lloyd et al., 1985). Heiman and BenJonathan (1982) noted that the $B_{\operatorname{mix}}$ in pituitaries from ovariectomized rats was high and subsequently decreased after estradiol treatment. The second new observation in the present study is that discontinuation of the DES after one week resulted in increased levels of dopamine receptors. Silastic tubes with $10 \mathrm{mg}$ of DES have been estimated to release approximately $45 \mu \mathrm{g} /$ day of this estrogen (Wiklund et al., 1981), thus the animals are receiving a pharmacologic dose of estrogens. Not surprisingly dopamine receptors were not detected after 2 and 3 weeks of DES treatment. The subsequent rebound effect after removal of the DES suggests that the presence of dopamine receptors and inhibition of tumor growth by DES may be related in some way, since the tumor resumed growth when the DES was discontinued (Lloyd et al., 1985). Alternatively, this relationship may be merely coincidental, since DES treatment in normal pituitary glands resulted in a decrease in dopamine receptors after 6 and 9 weeks in spite of continued proliferation of the pituitary cells (Lloyd, 1983). Although the $K_{\mathrm{d}}$ and $K_{\mathrm{i}}$ values were higher than some reported values in the literature (Cronin et al., 1980) these values are lower than other reported $K_{\mathrm{d}}$ and $K_{\mathrm{i}}$ values for $\left[{ }^{3} \mathrm{H}\right]$ spiperone binding to plasma membranes of pituitary tumors induced by estrone treatment (Eljarmax et al., 1985).

The MtT/W15 tumor has at least 2 cell populations, one producing GH and the other PRL although some of the cells may produce both PRL and GH (Parsons et al., 1978, 1980). Our recent experiments have shown that there is a shift in the population of GH and PRL cells after DES treatment with an increase in the GH-producing cells (Lloyd et al., 1985). This latter observation may possibly explain the decrease in dopamine receptors if a population of $\mathrm{GH}$ cells without dopamine receptors constitutes most of the cell population in DES-treated rats. The alternate hypothesis that DES treatment resulted in a decrease in the number of dopamine receptors per cell in the tumor cannot be excluded. The results seen in DEStreated normal pituitaries would support this latter view, because we and others have shown previously that there is an increase in the number of PRL cells after estrogen treatment in the normal pituitary gland (Lieberman et al., 1978; Lloyd, 1983). The observation that ovariectomy results in increased dopamine receptor density and a slower rate of tumor growth while DES decreases dopamine receptor density but also slows tumor growth is somewhat paradoxical and might suggest that DES may have only partial agonist activity compared to $17 \beta$-estradiol. However most of the available evidence from in vitro studies of $17 \beta$-estradioland DES on the synthesis of prolactin by primary cultures of dispersed anterior pituitary cells indicates that DES is a complete agonist of 17及-estradiol (Jordan and Lieberman, 1984).

The effects of chronic estrogen treatment on dopamine receptor levels have been quite variable (André et al., 1982; Bression et al., 1983; Di Paolo and Falardeau, 1984). André et al. (1982) did not find a significant decrease in the $B_{\max }$ in pituitary dopamine receptors after 90 days of estradiol treatment. Di Paolo and Falardeau (1984) found that after 25 weeks of estrogen treatment the $B_{\text {max }}$ was not significantly decreased in estradiol-induced pituitary tumors, although bromocriptine did produce a decrease in the $B_{\max }$. Other workers (Bression et al., 1983) have found a significant decrease in the $B_{\max }$ with chronic estrogen treatment which agrees with our present report. The 
dopamine receptor has recently been identified in an estrone-produced pituitary tumor, although it is not known if the receptor levels were decreased compared to those in normal pituitaries (Eljarmax et al., 1985). If one considers that the number of PRL cells increases by more than 2-fold in estrogen-induced pituitary tumors (Lloyd, 1983), then even if the number of dopamine receptors for estrogen-treated pituitaries remained constant, there would be a significant decrease in dopamine receptors if the receptors were expressed per mammotroph surface area (Cronin, 1982).

Previous studies have not found that DES or $17 \beta$-estradiol interfere with spiperone binding (Albaladejo et al., 1984). Although estrogen may be metabolized to catechol estrogens and thus interact with the dopamine receptor, the affinity of catechol estrogens for the dopamine receptor is low $\left(K_{\mathrm{d}}=0.2 \mu \mathrm{M}\right)$ (Schaeffer and Hsueh, 1979) and the procedure used for membrane preparation should be efficient in washing them out. Other investigators have shown that catechol estrogens do not interact at the same binding site as $\left[{ }^{3} \mathrm{H}\right]$ spiperone (Cronin and Weiner, 1979).

The dopamine receptors present in the $\mathrm{MtT} / \mathrm{W} 15$ tumors are indistinguishable from the dopamine receptors in normal anterior pituitary glands (Cronin et al., 1982). Nevertheless, the dopamine receptors in these tumors are considered to be functionless since the tumors are refractory to the dopaminergic inhibition of prolactin release (Lamberts and MacLeod, 1979). An analogous condition has also been reported with the 7315a tumor which produces PRL and ACTH (Cronin et al., 1981). The MtT/W15 and 7315a tumors are unlike other PRL-producing pituitary tumors, such as the $\mathrm{GH}_{3}$ cell line which does not have high-affinity dopamine receptors (Cronin et al., 1980). The finding of functionless receptors in the $\mathrm{MtT} / \mathrm{W} 15$ and 7315a PRL-secreting tumors correlates well with the previous findings that bromocriptine did not cause tumor regression or suppress elevated serum PRL levels in rats with these tumors (Lamberts and MacLeod, 1979).

Recent evidence suggests that the high-affinity agonist binding state of the D2 receptor in mediating the decrease in prolactin secretion occurs via attenuation of adenylate cyclase and is dependent on nucleotides (McDonald et al., 1984). The
MtT/W15 dopamine receptor has been found to be sensitive to guanine nucleotides suggesting that a $\mathrm{G} / \mathrm{F}$-like protein interacts with the dopamine receptor as it does in the normal anterior pituitary gland and that the functional defect in the MtT/W15 tumor probably does not occur at the cell membrane (Ross and Gilmore, 1980). However, it remains to be determined where the functional lesion in the MtT/W15 plasma membrane dopamine receptor is located.

\section{Acknowledgements}

This work was supported by NIH Grant IR23 CA37238, The University of Michigan Biomedical Support Research Grant RR05383, Cancer Research Grant No. IN-40W and a grant from the Michigan Memorial Phoenix Project. The authors thank Janssen Pharmaceuticals for haloperidol and spiperone, Sandoz for bromocriptine and Eli Lilly for Pergolide.

The authors thank Kimberlee Coleman and Vena Nath for technical assistance and ZoAnn Biddle and Sue Neely for typing the manuscript.

\section{References}

Albaladejo, V., Collu, R. and André, J. (1984) Endocrinology 114, 2344-2348.

André, J., Marchisio, A.M., Morel, Y, and Collu, R. (1982) Biochem. Biophys. Res. Commun. 106, 229-235.

Bradford, M.M. (1976) Ann. Biochem. 72, 248-251.

Bression, D., Brandi, A.M., LeDafniet, M., Cesselin, F., Hamen, M., Martinet. M., Kerdelhue, B. and Peillon, F. (1983) Endocrinology 113, 1799-1805.

Cronin, M.J. (1982) In: Neuroendocrine Perspectives, Vol. 1, Eds.: E.E. Muller and R.M. MacLeod (Elsevier Biomedical Press, Amsterdam) pp. 211-251.

Cronin, M.J. and Weiner, R.I. (1979) Endocrinology 104, $307-312$

Cronin, M.J., Fauve, N., Martial, J.A. and Weiner, R.I. (1980) Endocrinology 106, 718-723.

Cronin, M.J., Valdenegro, C.A., Perkins, S.N. and MacLeod, R.M. (1981) Endocrinology 109, 2160-2166.

Cronin, M.J., Keefer, D.A., Valdenegro, C.A., Dabney, L.G. and MacLeod, R.M. (1982) J. Endocrinol. 94, 347-358.

Di Paolo, T. and Falardeau, P. (1984) Biochem. Biophys. Res. Commun. 123, 312-316.

Eljarmax, D., Marchisio, A.M., Lis, M. and Collu, R. (1985) Horm. Res. 21, 107-116.

Furth, J., Clifton, K.H., Gadsden, E.L. and Buffett, R.F. (1956) Cancer Res. 16, 608-616.

Heiman, M.L. and Ben-Jonathan, N. (1982) Endocrinology $111,1057-1060$. 
Jorsan, V.C. and Lieberman, M.E. (1984) Mol. Pharmacol. 26, 279-285.

Lamberts, S.W.J. and MacLeod, R.M. (1979) Endocrinology $104,65-70$.

Lieberman, M.E., Maurer, R.A. and Gorski, J. (1978) Proc. Natl. Acad. Sci. U.S.A. 75, 5946-5949.

Lloyd, R.V. (1983) Am. J. Pathol. 113, 198-206.

Lloyd, R.V., Landefeld, T.D., Maslar, I. and Frohman, L.A. (1985) Am. J. Pathol. 118, 379-386.

McDonald, W.M., Sibley, D.R., Kilpatrick, B.F. and Coran, M.G. (1984) Mol. Cell. Endocrinol. 36, 201-209.

Morel, Y., Albaladejo, V., Bouvier, J. and André, J. (1982) Cancer Res. 42, 1492-1497.
Parsons, J.A., Erlandson, S.L., Carpenter, A.M. and Debault, L.E. (1978) Anat. Rec. 190, 719-734.

Parsons, J.A., Boskin, D.G. and Erlandsen, S.L. (1980) Anat. Rec. 196, 301-311.

Ross, E.M. and Gilmore, A.G. (1980) Ann. Rev. Biochem. 49 , 533-564.

Scatchard, G. (1949) Ann. N.Y. Acad. Sci. 51, 660-666.

Schaeffer, J.M. and Hsueh, A.J.W. (1979) J. Biol. Chem. 254, 5606-5608.

Wiklund, J., Wertz, N. and Gorski, J. (1981) Endocrinology $109,1700-1707$. 